\title{
IDENTIFYING POTENTIAL SOLUTIONS FOR SPECIFIC REVERSE LOGISTICS PROBLEMS
}

\author{
A BADENHORST* \\ JD NEL** \\ *badena@unisa.ac.za \\ **neljd@unisa.ac.za \\ Department of Transport Economics, Logistics and Tourism \\ University of South Africa (Unisa).
}

\begin{abstract}
The concept of reverse logistics is often misunderstood and academic research in this field is limited, especially in South Africa. The research for this article was based on the available literature. Various international sources and a limited number of South African sources were studied in an attempt to explore the concept of reverse logistics, and identify possible problems and potential solutions to such reverse logistics problems. There are several definitions of reverse logistics and the term is often confused with other terms such as returns management. Various problems and challenges also exist in reverse logistics; however, solutions have been proposed to address these problems. The research presented in this article clearly shows that a variety of opportunities exists in the field of reverse logistics in South Africa, with regard to research as well as the proper implementation and management of reverse logistics in business.
\end{abstract}

\section{INTRODUCTION}

Traditionally, reverse logistics, which is essentially the opposite of logistics (Council of Supply Chain Management Professionals, 2010: 114), has not enjoyed an attractive reputation because of the misconception that it is only a cost drain which does not add any value to the supply chain (Mukhopadhyay \& Setaputra, 2006: 716). However, during the last decade, reverse logistics has attracted more attention due to competition and marketing motives, direct economic motives and environmental concerns, as well as strategic and managerial implications (Ravi \& Shankar, 2004: 2; Dowlatshahi, 2005: 3456). With legislative measures also becoming more restrictive, organisations do not have any choice but to engage in reverse logistics practices (Ravi \& Shankar, 2004: 2). Growing emphasis on customer satisfaction, the liberalisation of return policies, and the reuse of parts have lengthened product life cycles. This has resulted in an increase in backward flow of products through the supply chain, placing more emphasis on reverse logistics (Schwartz, 2000: 95). Organisations are now beginning to realise that reverse logistics is important in that it can be extremely cost-effective and deliver significant added value to the customer's overall experience of 
the organisation or brand, if handled and managed correctly (Weers, 2008: 36). Reverse logistics can be a major source of untapped profitability for organisations (Sumner, 2008: 1) and a well-managed reverse logistics programme can distinguish an organisation from competitors and increase customer loyalty (Dampier, 2006: 22).

It seems that businesses and supply chains in South Africa fail to realise the importance of reverse logistics. In the 2011 supplychainforesight annual research report, only $3 \%$ of the respondents in major supply chains indicated that reverse logistics was an important objective that they would pursue the following year (supplychainforesight, 2011: 9). The question is whether organisations understand reverse logistics and know how to overcome the challenges or problems of reverse logistics. The main objective of this article is to explore the concept of reverse logistics and the possible problems and potential solutions associated with reverse logistics.

\section{LITERATURE STUDY}

\section{Defining reverse logistics}

There is a wide range of definitions for reverse logistics. According to Vogt, Pienaar and De Wit (2002: 234) the reason for the variety of definitions is that reverse logistics is 'one of the fastest developing fields in business logistics', which results in constant changes in scope and significance. From the introduction, it seems that South African organisations are lagging behind in this 'fast developing field'.

The Council of Supply Chain Management Professionals (CSCMP, 2010: 151) defines reverse logistics as a 'specialised segment of logistics focusing on the movement and management of products and resources after the sale and after delivery to the customer'. Reverse logistics is also described as 'a concept aimed at waste and cost reduction in the distribution channel by creating procedures to reverse the distribution process' (Hugo, Badenhorst-Weiss \& Van Biljon, 2004: 225). Vogt et al. (2002: 234) describe the concept in more detail. According to them, reverse logistics is

the management of all activities involved in goods, demand information, and money flowing in the opposite direction of the primary logistics flow. It involves reducing the generation of waste, as well as managing the collection, transport, disposal, and recycling of both hazardous and non-hazardous waste in a way that maximises the long-term profitability of the business.

Reverse logistics is also defined as the

process of planning, implementing, and controlling the efficient, cost effective flow of raw materials, in-process inventory, finished goods and related information from 
the point of consumption to the point of origin for the purpose of recapturing value or proper disposal (Rogers \& Tibben-Lembke, 1998: 268).

With, reverse logistics, organisations systematically accept previously shipped products or parts from the point of consumption for possible recycling, remanufacturing or disposal (Dowlatshahi, 2000: 143). Guide, Jayaraman, Srivastava and Benton (2000: 136) define reverse logistics as 'the task of recovering discarded products; it may include packaging and shipping materials and backhauling them to a central collection point for either recycling or remanufacturing'.

Reverse logistics encompasses logistics activities all the way from used products that are no longer required by the user to products that are again usable in a market. It involves the physical transportation of used products from the end user to a producer (Fleischmann, Bloemhof-Ruwaard, Dekker, Van der Laan, Van Nunem \& Van Wassenhove, 1997: 2). Reverse logistics can include all of the activities required to move a product from point of use to point of disposal (Blumberg, 1999: 145).

Various authors are of the opinion that the entire process of reverse logistics starts at the point of consumption. However this could be misleading because reverse logistics could also start at retailers and distributors (who are not consumers of the products) (Zuluaga, 2005: 19). In the same way, 'point-of-origin' is also misleading - it is not necessarily the correct way to describe reverse logistics. It should rather be the 'point of recovery' since flows may go back to other points (De Brito, 2003: 20).

From the above definitions and descriptions of reverse logistics, a number of conclusions can be drawn. First, some authors define reverse logistics as a set of logistics management tasks or activities, while most of them define it as a process. Secondly, some definitions contain the inputs in reverse logistics, which, most authors agree, include discarded products, used products, products or parts previously shipped, and hazardous and nonhazardous waste. Others look at reverse logistics as a broader concept that includes the entire reverse flow of information, raw materials, inventories and goods through the supply chain. Thirdly, included in the definitions are the tasks and activities that are all similar to the activities performed in forward logistics, and some additional tasks. Reverse logistics activities include planning, implementing and controlling an efficient and cost-effective flow of products, as well as the collection, transportation, recovery, storage, processing, acceptance, reduction, management, disposal, and shipping of products (Zuluaga, 2005: 17-19).

\section{Related concepts}

The above discussion of reverse logistics, substantiated by various definitions or descriptions, makes it clear that the views on reverse logistics are multi-dimensional. 
What complicates matters is that there are closely related concepts or terms that are sometimes used as synonyms for reverse logistics. These terms include closed-loop supply chain management (CSCM); reverse supply chain management (RSCM); green logistics and green supply chain management (GSCM); recycling; and returns management.

Before closed-loop supply chain management can be defined, an outline of the concept of supply chain management (SCM) is necessary. According to the CSCMP (2010), SCM is

the planning and management of all activities involved in sourcing and procurement, conversion, and all logistics management activities. Importantly, it also includes coordination and collaboration with channel partners, which can be suppliers, intermediaries, third-party service providers, and customers. In essence, supply chain management integrates supply and demand management within and across companies. Supply chain management is an integrating function with primary responsibility for linking major business functions and business processes within and across companies into a cohesive and high-performing business model. It includes all of the logistics management activities with and across marketing, sales, product design, finance and information technology.

Closed-loop supply chains (CSC) are formed when forward and reverse supply chain activities are combined into a single system with the aim of integrating returned products back into the distribution network (Kussing \& Pienaar, 2009: 433). Closed-loop supply chain management (CSCM) can be defined as the management of 'supply chains that are designed to consider the acquisition and return of products, reuse activities, and the distribution of the recovered products' (Rogers, Lambert, Croxton \& García-Dastugue, 2002: 5). CSCM can also be defined as the 'design, control and operation of a system to maximise value creation over the entire life-cycle of a product with dynamic recovery of value from different types and volumes of returns over time' (Guide \& Van Wassenhove, 2006: 349). Closed loops involve forward as well as backward logistics across organisational boundaries. Reverse logistics is thus part of CSCM.

A reverse supply chain is a series of activities involved in retrieving a used or unused product from a customer and either disposing, reusing or reselling it (Guide \& Van Wassenhove, 2002: 25). Reverse supply chain management (RSCM) is the automation of business processes to manage the reverse path of a product from the customer to its final disposal across the entire supply chain and includes:

- managing product returns, real-time inventory, and workflow

- tracking warranties

- ordering and exchanging parts 
- collaborating with suppliers

- analysing data

- performing repairs

- de-manufacturing

- re-disposal and customer notification.

If compared with the definition of reverse logistics formulated earlier in the article, it is clear that reverse logistics is inherently part of RSCM.

Reverse logistics is also closely related to green logistics in terms of overlapping goals with regard to issues of reuse, recycling and waste disposal (Kussing \& Pienaar, 2009: 423). According to the Reverse Logistics Executive Council (RLEC), green logistics 'attempts to measure and minimise the ecological impact of logistics activities'. Green logistics is thus a part of reverse logistics.

Srivastava (2007: 54-55) defines green supply chain management (GSCM) as 'integrating environmental thinking into supply chain management, including product design, material sourcing and selection, manufacturing processes, delivery of the final product to the consumers, as well as end-of-life management of the product after its useful life'. Green logistics and reverse logistics are part of GSCM. Elements of reverse logistics and green logistics are easily identified in the sub-parts of GSCM (Hervani, Helms \& Sarkis, 2005: 334).

Recycling is one of the disposal options available to organisations and forms part of the activities and processes in reverse logistics. Recycling is the process where used products, components and materials are collected, disassembled and separated into categories of similar materials. They are then processed into recycled materials (Mangan, Lalwani, Butcher \& Javadpour, 2012: 342). Recycling therefore involves the reduction of products to their basic elements that are then reused (Rogers \& Tibben-Lembke, 1998: 261).

According to Rogers etal. (2002: 5), returns management is 'part of supply chain management, which includes reverse logistics'. Returns management 'includes the informational support of the entire returns process, including arrangements for transportation and physical handling' (Norek, 2002: 36). Reverse logistics encompasses only the backward movement of materials in the supply chain, whereas returns management is much broader in scope. Returns management requires collaboration and interaction between members of the supply chain; thus, it is a boundary-spanning activity. In other words, it is a critical element and requires planning and effective implementation across supply chain firms (Rogers et al., 2002: 1).

It can be concluded that some of the above-mentioned concepts have a semantic overlap with reverse logistics. This is illustrated in Figure 1. Reverse logistics forms part of the broader 
concepts of closed-loop supply chain management, reverse supply chain management, and returns management. It is thus clear from the above that concepts that are related to reverse logistics differ, often just slightly, in scope and emphasis. What is also clear is that reverse logistics and its related concepts recognise forward and backward flow of materials and information and aim to minimise waste and the environmental impact to the advantage of society and the organisation or supply chain.

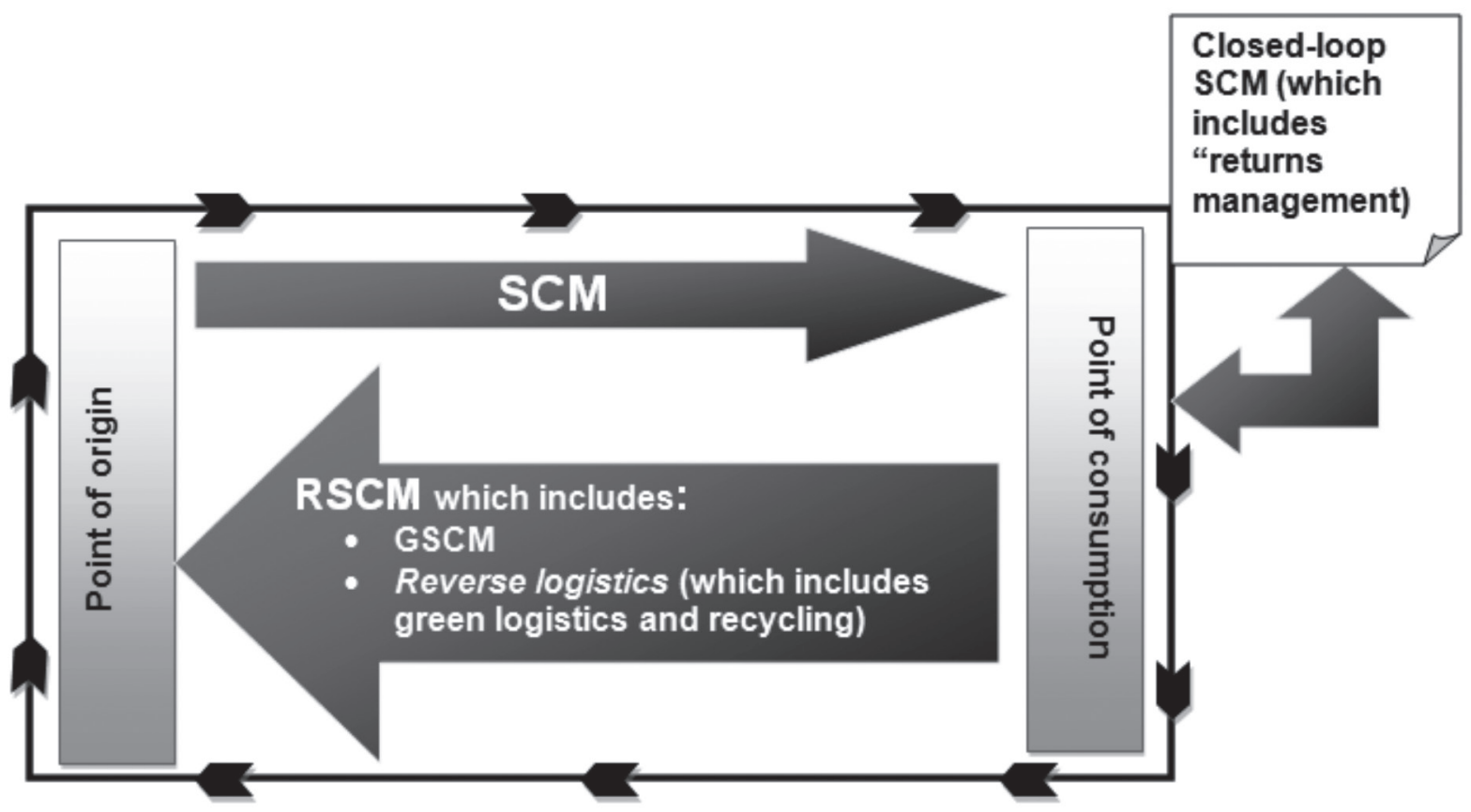

Figure 1: Reverse logistics and related concepts

(Source: Compiled by authors)

Organisations therefore need to recognise the importance of reverse logistics. From the discussion about reverse logistics, it is evident that reverse logistics has to be managed. Organisations need to ask themselves if they are aware of the reverse logistics activities and processes in their organisations and if they are managing these activities and processes. It is evident that reverse logistics has several inherent barriers and problems that need to be addressed.

\section{PROBLEMS WITH REVERSE LOGISTICS}

According to Min, Kim and Ha (2006: 94) reverse logistics is by its very nature a complex process and a specialised area of any supply chain. It does not matter what the product is, how it is sold or who the customers are; every organisation needs to focus on recovering the maximum value from returns. As indicated earlier there is a negative attitude in business towards reverse logistics and there are some problems that can be identified with reverse logistics. 


\section{Costs related to reverse logistics}

One of the biggest pressures on organisations with regard to reverse logistics is the internal mandate to reduce costs (Pollock, 2010: 8). The main aim of product sales is forward sales (or downstream sales) towards the customers. These sales are based on demand planning and forecasts. Organisations do not plan for products to 'fail' and enter the reverse logistics stream. In a perfect world, products are manufactured and sold to customers and do not become part of the reverse logistics process. Therefore, initially, reverse logistics is not considered as a revenue-generating process, which consequently results in very few resources being allocated to this part of the supply chain (Rogers \& Tibben-Lembke, 2001: 141). However, some organisations have seized the opportunity to generate income from their reverse logistics processes. The increase in costs for processing returns is higher compared with a forward sale and it could cost up to three times more to process the reverse logistics of a new item than it would to process the forward logistics to sell it (Norman, 2007: 2).

\section{Insufficient information systems}

Insufficient investment in information technology and a lack of information systems are major barriers to the successful management and implementation of reverse logistics (Ravi \& Shankar, 2004: 3; Zheng, Zheng \& Liu, 2005: 852; Jayaraman, Ross \& Agarwal, 2008 : 414). Many enterprise resource planning (ERP), customer relationship management (CRM) and warehouse management systems (WMS) are not set up efficiently to take back products (Norman, 2007: 1). Most organisations live with labour-intensive, manual, inefficient, and often undisciplined reverse logistics processes (Thrikutam \& Kumar, 2004: 1). Very few organisations have successfully automated information systems in the return process, and the resources allocated to these systems are also stretched to the limit and are unavailable for reverse logistics applications (Rogers \& Tibben-Lembke, 1998: 43; Jayaraman et al., 2008: 414).

\section{Uncertainties related to product returns}

Returns come from different locations and in different conditions, with different disposal options (Rogers in Richardson, 2006: 2). A great deal of uncertainty surrounds product returns in terms of the kind of product, the quantities, when the product returns will take place, where in the supply chain the return will take place, and what the condition and quality of the returned products will be. The majority of product returns are unplanned and therefore unpredictable (Mason, 2002: 43; Jayaraman \& Luo, 2007: 60; Kussing \& Pienaar, 2009: 429). Product returns can therefore take on a wide variety of forms and can come from various organisations in the supply chain. Return processing is highly dynamic and inconsistent and is complex because it involves irregular material flows (Hart, 2008: 12). 


\section{Customers' negative perceptions about product returns}

Returning products to an organisation automatically carries with it a negative connotation in the mind of the customer (Dampier, 2006: 22). Customers' perceived expectations are an important aspect for any organisation, especially when customers receive products that do not meet their expectations (Riedel, 2004: 1). This can have a negative impact on the organisation's relationship with its customers (Riedel, 2004: 1; Dampier, 2006: 22).

\section{Organisations' resistance towards new approaches and change}

The reverse flows may also involve an entirely different channel that requires new approaches (Norek, 2002: 42; Richey, Daugherty \& Genchev, 2005a: 235). Resistance to change in the organisation can therefore be a problem because reverse logistics requires drastic changes in both mindset and practice (Ravi \& Shankar, 2004: 5). To have a successful reverse logistics process in place requires a shift in the organisation. Many organisations' policies and structures get in the way of the change necessary for the successful implementation of reverse logistics (Ravi \& Shankar, 2004: 5).

\section{POTENTIAL SOLUTIONS TO REVERSE LOGISTICS PROBLEMS}

To overcome the problems of reverse logistics, it is necessary to direct organisations' attention towards the possible benefits or opportunities of efficiently managed reverse logistics. As already mentioned, reverse logistics has a cost implication. If the reverse logistics process is managed correctly, it can minimise logistics costs and improve revenue (Bernon, Rossi \& Cullen, 2011: 22). Therefore effective reverse logistics management can add significantly to an organisation's profitability (Mollenkopf \& Weathersby, 2004: 1) by minimising unnecessary costs. In the United States of America (USA), a study of more than 160 manufacturers and service providers conducted in 2010 by the Aberdeen Group, revealed that $87 \%$ of organisations had indicated that the effective management of the reverse supply chain was either 'extremely important' or 'very important' to their operational and financial performance (Pollock, 2010: 8). Harps (2003: 1) found that some organisations achieved cost reduction and service level improvements of $50 \%$ or more by optimising reverse logistics. Hammrich (2007: 28-29), on the other hand, found that the effective management of returns can reduce the cost of returns by as much as $73 \%$. Therefore, from a logistics perspective, an effective reverse logistics programme can reinsert returned products into the forward supply chain. This in turn, generates additional revenue, reduces operating cost and minimises opportunity costs of writing off defective or out-of-date products (Mollenkopf \& Closs, 2005: 35). The question can now be asked: How can a reverse logistics programme be managed? The answer lies in the following possible benefits of, or opportunities in, reverse logistics which were identified during the literature study. 


\section{Emphasise strategic and marketing benefits}

Reverse logistics offers organisations the opportunity to generate additional revenue, differentiate their market position, and support the original demand for the product. Therefore, reverse logistics offers organisations important strategic and marketing benefits in today's dynamic marketplace if organisations provide customers and business partners with the opportunity to send back defective or unwanted products quickly and receive credit in a timely fashion (Rust, Lemon \& Narayandas, in Richey, Tokman, Wright \& Harvey, 2005b: 47).

\section{Allocate adequate resources to reverse logistics programmes}

If adequate resources are allocated to reverse logistics programmes, it can result in a positive financial impact (Genchev, Landry, Daugherty \& Roath, 2010: 14). Investing in effective reverse logistics planning will offer organisations significant opportunities, such as building improved relationships with customers, salvage revenue, and learning from past mistakes (Brewer, 2007: 33). Therefore, when resources are allocated to reverse logistics, organisations will be able to develop innovative reverse logistics capabilities, which will enhance the performance of the organisation and its competitive differentiation (Richey et al., 2005a: 234). Organisations will also be able to re-engineer their business processes to get a better understanding of future practices. With an efficient reverse logistics process in place, organisations can benefit from valuable information resources that can enhance the returns process, improve the design of products and manufacturing quality, indicate problems with packaging, as well as draw attention to marketing issues (Zheng et al., 2005: 815). Reverse logistics can also present organisations with the opportunity to engage in individualised promotions, flexible marketing campaigns and improved credit processing (Sciarotta in Biederman, 2006: 4).

\section{Comply with government regulations to achieve environmental benefits}

Reverse logistics has become an imperative, especially due to the economic, environmental and legislative pressures faced by organisations (Ravi \& Shankar, 2004: 2). Reverse logistics programmes can reduce the threat of government regulations, which, in turn, can boost the corporate image of an organisation (Carter \& Ellram, 1998: 85).

Therefore, effective returns management and reverse logistics can increase organisations' environmental compliance (Kussing \& Pienaar, 2009: 424). Reverse logistics programmes may also have a positive effect on global industries where controlled waste disposal benefits all stakeholders by protecting natural resources as well as other industries (Richey et al., 2005b: 53).

Countless environmental-related benefits can result from an effective reverse logistics programme. For instance, through the use of pollution prevention, a company can 
coordinate and market an effort that incorporates product refurbishment, process modification, equipment redesign and reuse of waste materials to minimise the introduction of non-usable waste into the environment. Organisations can reduce the generation of waste with the prioritisation of waste prevention, reuse and recycling (Moore, 2006: 6). With reverse logistics organisations can also recycle products or packaging to improve their environmentally friendly practices.

With the increase in costs due to practices that seek to minimise the impacts on natural resources, reverse logistics can become a production procedure that will minimise environmental impacts at lower costs (Flávia, Bernardi, Da Rocha \& Camargo, 2010: 37). Reverse logistics can facilitate the organisation to be more cost-effective and ecologically friendly by extending a product's normal life cycle beyond traditional usage (Melbin in Dowlatshahi, 2000: 144). In addition, reverse logistics can reduce costs by reusing products, components and materials instead of simply disposing of them into landfills which negatively impacts the environment (Yimsiri, 2009: 1).

\section{Analyse the reasons for customer returns}

Understanding return processes in reverse logistics will help organisations to gain more insight into the sales patterns of items and how often goods are returned (and why). This information can have a great impact on the overall reverse logistics programme (Hammrich, 2007: 28-29). Reverse logistics can provide the organisation with an opportunity to capture valuable data to help future manufacturing, packaging and marketing decisions where the organisation can proactively take steps to increase customer satisfaction by analysing the reasons why customers return products (Kim, 2001: 2). It allows organisations to differentiate themselves in the customers' eyes. High-quality reverse logistics can promote long-term relationships where the customers are more likely to repurchase if the organisation does a good job in handling returns (Daugherty, Myers \& Richey, 2002: 86). According to Riedel (in Biederman, 2004: 1), returns are a key contributor to customer retention, and having a good returns system will help to drive sales, provide valuable data on what products are coming back, as well as promote collaboration between supply chain members. Customers prefer reduced risk when selecting a supplier with efficient reverse logistics processes in place, which can make the organisation more agile (Rogers \& Tibben-Lembke, 2001: 145). High-quality reverse logistics can promote long-term relationships where the customers are more likely to repurchase if the organisation does a good job in handling returns (Daugherty et al., 2002: 86).

\section{ALIGNING POTENTIAL SOLUTIONS TO SPECIFIC REVERSE LOGISTICS PROBLEMS}

The objectives of this article were to explore the concept of reverse logistics as well as the problems and possible solutions to these problems. The problems identified in the article can be summarised as follows: 
- Costs related to reverse logistics

- Insufficient information systems

- Uncertainties related to product returns

- Customers' negative perceptions about product returns

- Organisations' resistance towards new approaches and change.

The following broad or general potential solutions to reverse logistics problems were also identified:

- Emphasise strategic and marketing benefits.

- Allocate adequate resources to reverse logistics programmes.

- Comply with government regulations to achieve environmental benefits.

- Analyse the reasons for customer returns.

Organisations have to manage their reverse logistics programmes to benefit from these potential solutions. The article proposes specific solutions to overcome each of the barriers or problems of reverse logistics. Table 1 summarises the broad problems of reverse logistics as well as the potential solutions that are suggested for each one of these problems.

Table 1: Reverse logistics problems and potential solutions

\begin{tabular}{|c|c|c|}
\hline $\begin{array}{l}\text { Reverse } \\
\text { logistics } \\
\text { problems }\end{array}$ & Potential solutions & Potential benefits (or opportunities) \\
\hline \multirow[t]{3}{*}{$\begin{array}{l}\text { Costs related } \\
\text { to reverse } \\
\text { logistics }\end{array}$} & $\begin{array}{l}\text { Emphasise strategic } \\
\text { and marketing } \\
\text { benefits. }\end{array}$ & $\begin{array}{l}\text { Organisations should emphasise the opportunity to: } \\
\text { 1) generate additional revenue } \\
\text { 2) differentiate their market position } \\
\text { 3) support the original demand for the product. }\end{array}$ \\
\hline & $\begin{array}{l}\text { Allocate adequate } \\
\text { resources to } \\
\text { reverse logistics } \\
\text { programmes. }\end{array}$ & $\begin{array}{l}\text { Organisations will be able to: } \\
\text { 1) develop innovative reverse logistics capabilities } \\
\text { 2) re-engineer business processes to enhance returns processes } \\
\text { and improve the forward flow of products. }\end{array}$ \\
\hline & $\begin{array}{l}\text { Analyse the reasons } \\
\text { for customer returns. }\end{array}$ & $\begin{array}{l}\text { Organisations can then: } \\
\text { 1) differentiate themselves in the eyes of their customers which } \\
\text { improves customer service } \\
\text { 2) build long-term relationships with their customers. }\end{array}$ \\
\hline \multirow[t]{3}{*}{$\begin{array}{l}\text { Insufficient } \\
\text { information } \\
\text { systems }\end{array}$} & $\begin{array}{l}\text { Emphasise strategic } \\
\text { and marketing } \\
\text { benefits. }\end{array}$ & $\begin{array}{l}\text { Organisations should emphasise the opportunity to: } \\
\text { 1) generate additional revenue } \\
\text { 2) differentiate their market position } \\
\text { 3) support the original demand for the product. }\end{array}$ \\
\hline & $\begin{array}{l}\text { Allocate adequate } \\
\text { resources to } \\
\text { reverse logistics } \\
\text { programmes. }\end{array}$ & $\begin{array}{l}\text { Organisations will be able to: } \\
\text { 1) develop innovative reverse logistics capabilities } \\
\text { 2) re-engineer business processes to enhance returns processes } \\
\text { and improve the forward flow of products. }\end{array}$ \\
\hline & $\begin{array}{l}\text { Analyse the reasons } \\
\text { for customer returns. }\end{array}$ & $\begin{array}{l}\text { Organisations can then: } \\
\text { 1) differentiate themselves in the eyes of their customers which } \\
\text { improves customer service } \\
\text { 2) build long-term relationships with their customers. }\end{array}$ \\
\hline
\end{tabular}




\begin{tabular}{|c|c|c|}
\hline $\begin{array}{l}\text { Uncertainties } \\
\text { related to } \\
\text { product returns }\end{array}$ & $\begin{array}{l}\text { Allocate adequate } \\
\text { resources to } \\
\text { reverse logistics } \\
\text { programmes. }\end{array}$ & $\begin{array}{l}\text { Organisations will be able to: } \\
\text { 1) develop innovative reverse logistics capabilities } \\
\text { 2) re-engineer business processes to enhance returns processes } \\
\text { and improve the forward flow of products. }\end{array}$ \\
\hline & $\begin{array}{l}\text { Analyse the reasons } \\
\text { for customer returns }\end{array}$ & $\begin{array}{l}\text { Organisations can then: } \\
\text { 1) differentiate themselves in the eyes of their customers which } \\
\text { improves customer service } \\
\text { 2) build long-term relationships with their customers. }\end{array}$ \\
\hline \multirow[t]{3}{*}{$\begin{array}{l}\text { Customers' } \\
\text { negative } \\
\text { perceptions } \\
\text { about product } \\
\text { returns }\end{array}$} & $\begin{array}{l}\text { Allocate adequate } \\
\text { resources to } \\
\text { reverse logistics } \\
\text { programmes. }\end{array}$ & $\begin{array}{l}\text { Organisations will be able to: } \\
\text { 1) develop innovative reverse logistics capabilities } \\
\text { 2) re-engineer business processes to enhance returns processes } \\
\text { and improve the forward flow of products. }\end{array}$ \\
\hline & $\begin{array}{l}\text { Comply with } \\
\text { government } \\
\text { regulations. }\end{array}$ & $\begin{array}{l}\text { 1) Organisations' corporate image is improved. } \\
\text { 2) Natural resources and other industries are protected. } \\
\text { 3) Waste generation is reduced. }\end{array}$ \\
\hline & $\begin{array}{l}\text { Analyse the reasons } \\
\text { for customer returns. }\end{array}$ & $\begin{array}{l}\text { Organisations can then: } \\
\text { 1) differentiate themselves in the eyes of their customers which } \\
\text { improves customer service } \\
\text { 2) build long-term relationships with their customers. }\end{array}$ \\
\hline \multirow[t]{3}{*}{$\begin{array}{l}\text { Organisations' } \\
\text { resistance } \\
\text { towards new } \\
\text { approaches } \\
\text { and change }\end{array}$} & $\begin{array}{l}\text { Emphasise strategic } \\
\text { and marketing } \\
\text { benefits. }\end{array}$ & $\begin{array}{l}\text { Organisations should emphasise the opportunity to: } \\
\text { 1) generate additional revenue; } \\
\text { 2) differentiate their market position; } \\
\text { 3) support the original demand for the product }\end{array}$ \\
\hline & $\begin{array}{l}\text { Allocate adequate } \\
\text { resources to } \\
\text { reverse logistics } \\
\text { programmes. }\end{array}$ & $\begin{array}{l}\text { Organisations will be able to: } \\
\text { 1) develop innovative reverse logistics capabilities } \\
\text { 2) re-engineer business processes to enhance returns processes } \\
\text { and improve the forward flow of products. }\end{array}$ \\
\hline & $\begin{array}{l}\text { Comply with } \\
\text { government } \\
\text { regulations. }\end{array}$ & $\begin{array}{l}\text { 1) Organisations' corporate image is improved. } \\
\text { 2) Natural resources and other industries are protected. } \\
\text { 3) Waste generation is reduced. }\end{array}$ \\
\hline
\end{tabular}

\section{CONCLUSION}

The research discussed in this article was based on the literature in which reverse logistics was explored. It was found that there are negative attitudes towards reverse logistics. Most businesses and workers are not aware of the potential benefits of or opportunities presented by correctly managed reverse logistics. It was also pointed out that, because of the semantic overlap between terms used in this field, the term 'reverse logistics' is often confused with other terms such as closed-loop supply chains and closed-loop supply chain management, reverse supply chain and reverse supply chain management, green logistics and green supply chain management, recycling and returns management. This article attempted to dispel some of the confusion in this regard.

There are several generic problems in reverse logistics. However, there are also potential solutions to these problems. Table 1 summarises the potential solutions for each of the mentioned problems of reverse logistics. From Table 1 it is clear that there are some potential solutions that can be suggested for all (or most of) the problems of reverse 
logistics. These solutions are first, that organisations have to allocate adequate resources to reverse logistics programmes. Secondly, organisations have to analyse the reasons for customer returns. In doing so, organisations may overcome many of the problems experienced with reverse logistics.

This study was based mainly on international and a few local literature sources only. No scientific research studies or articles could be found in the South African literature and therefore the conclusion can be made that there is a lack of research in the field of reverse logistics in South Africa; consequently, there are many research and business opportunities in the field of reverse logistics. It is a matter of overcoming the lack of awareness of the potential benefits and opportunities offered by the efficient management of reverse logistics. This study can serve as a foundation for further empirical studies on the subject of reverse logistics in South Africa.

It is important for organisations to realise that, if they do not offer a full complement of basic reverse logistics support services, they will fall behind their competitors who do (Pollock, 2007: 16). Reverse logistics is no longer just a sub-process but rather a major driver for securing a competitive advantage in an age of demanding customers (Min et al., 2006: 94). Therefore, organisations have to manage their reverse logistics processes. By emphasising and focusing on the benefits that can be achieved with reverse logistics, organisations may overcome the problems of reverse logistics and achieve a competitive advantage.

\section{REFERENCES}

Bernon, M., Rossi, S. \& Cullen, J. 2011. Retail reverse logistics: a call and grounding framework for research. International Journal of Physical Distribution and Logistics Management, 41(5):484-510. Available from: www.emeraldinsight.com/0960-0035.htm (Accessed 29 November 2011).

Biederman, D. 2004. Reversing inventory management. Traffic World. 20-22. Available from: http://www.proquest.com (Accessed 15 October 2007).

Biederman, D. 2006. Planning for happy returns. Traffic World. Available from: http:// proquest.umi.com (Accessed 15 June 2009).

Blumberg, D.F. 1999. Strategic examination of reverse logistics and repair service requirements, needs, market size, and opportunities. Journal of Business Logistics, 20(2):141-59.

Brewer, C. 2007. Product recalls: now what? Reverse Logistics Magazine, 6th ed., 3(2):3335. Available from: www.RLmagazine.com (Accessed 26 January 2008). 
Carter, C.R. \& Ellram, L. 1998. Reverse logistics: a review of literature and framework for future investigation. Journal of Business Logistics, 9(1):85-102. Available from: http://www. proquest.com (Accessed 1 November 2007).

Council of Supply Chain Management Professionals (CSCMP). 2010. Supply chain and logistics terms and glossary. Available from: http://cscmp.org/digital/glossary/glossary.asp (Accessed 25 June 2010).

Dampier, J. 2006. Leveraging reverse logistics to increase customer loyalty and operational efficiency. Reverse logistics magazine, 1(1): 22-23. Available from: www. RLmagazine.com (Accessed 12 February 2007).

Daugherty, P.J., Myers, M.B. \& Richey, R.G. 2002. Information support for reverse logistics: the influence of relationship commitment. Journal of Business Logistics, 23(1):85-106. Available from: http://www.proquest.com (Accessed 1 November 2007).

De Brito, M.P. 2003. Managing reverse logistics or reversing logistics management? Ph.D. ERIM PhD Series Research in Management, 35. Erasmus Research Institute of Management (ERIM). Erasmus Unversity Rotterdam. Available from: www.erim.eur.nl (Accessed 15 January 2008).

Dowlatshahi, S. 2000. Developing a theory of reverse logistics. Transportation - Freight/ Materials Handling, Environment, Interfaces 30(3):143-51.

Dowlatshahi, S. 2005. A strategic framework for the design and implementation of remanufacturing operations in reverse logistics. International Journal of Production Research, 43(16):3455-80.

Flávia, C.R., Bernardi, C. Da Rocha, J.M. \& Camargo, M.E. 2010. Strategic reasons, factors and advantages leading companies to reverse logistics: a case study. Global Journal of Management and Business Research, 10(6):37-48. Available from: http://globaljournals.org/ GJMBR_Volume10/5-Strategic-Reasons-Factors-and-Advantages-Leading.pdf (Accessed 12 September 2011).

Fleischmann, M., Bloemhof-Ruwaard, J.M., Dekker, R., Van der Laan, E., Van Nunem, J. \& Van Wassenhove, L.N. 1997. Quantitative models for reverse logistics: a review. European Journal of Operational Research, 103(1):1-17. Available from: www.sciencedirect.com (Accessed 1 November 2007).

Genchev, S.E., Landry, T.D., Daugherty, P.J. \& Roath, A.S. 2010. Developing reverse logistics programs: a resource based view. Journal of Transportation Management, 21(1):7-26. 
Guide, D., Jayaraman, V., Srivastava, R. \& Benton, W. 2000. Supply chain management for recoverable manufacturing systems'. Interface, 30(3):125-42.

Guide, V.D.R. \& Van Wassenhove, L.N. 2002. The reverse supply chain. Harvard Business Review, 80(2):25-26.

Guide, V.D.R. \& Van Wassenhove, L.N. 2006. Closed-loop supply chains: an introduction to the feature issue (part 1). Production and Operations Management, 15(3):345-50.

Hammrich, D. 2007. Taking a look back helps retailers stay a step ahead: tapping into hidden revenues with returns management. Reverse Logistics Magazine, 2(2):28-29. Available from: www.RLmagazine.com (Accessed 23 January 2008).

Harps, L.H. 2003. Revving up returns. Inbound Logistics. Available from: http://www. inboundlogistics.com/articles/features/1103_feature02.shtml (Accessed 5 October 2007).

Hart, B. 2008. Reverse logistics: strengthening the forgotten supply chain. Reverse Logistics Magazine, 3(2):12-16. Available from: www.RLmagazine.com (Accessed 5 May 2011).

Hervani, A.A., Helms, M.M. \& Sarkis, J. 2005. Performance measurement for green supply chain management. Benchmarking, 12(4):330-53. Available from: http://www.proquest. com (Accessed 23 November 2007).

Hugo, W.M.J., Badenhorst-Weiss, J.A. \& Van Biljon, E.H.B. 2004. Supply Chain Mangagement - Logistics Perspective. Pretoria: Van Schaik Publishers.

Jayaraman, V. \& Luo, Y. 2007. Creating competitive advantages through new value creation: a reverse logistics perspective. Academy of Management Perspectives, 21(2):56-73. Available from: http://www.ebscohost.com (Accessed 15 February 2009).

Jayaraman, V., Ross, A.D. \& Agarwal, A. 2008. Role of information technology and collaboration in reverse logistics supply chains. International Journal of Logistics Research and Applications, 11(6):409-25.

Kim, H. 2001. Manufacturers profit by managing reverse supply chains. Logistics Management. Available from: http://www.logisticsmgmt.com/article/CA73190.html (Accessed 15 June 2007).

Kussing, U. \& Pienaar, W.J. 2009. Business logistics management: a supply chain perspective. In: Pienaar, W.J. \& Vogt, J.J. (3rd ed.). South Africa: Oxford University Press, 421-37. 
Mangan, J., Lalwani, C., Butcher, T. \& Javadpour, R. 2012. Global logistics and supply chain management. (2nd ed.) Chicester:Wiley.

Mason, S. 2002. Backward progress: turning the negative perception of reverse logistics into happy returns. IIE Solutions. Available from: http://www.highbeam.com/doc/1G1-90464873. html (Accessed 12 September 2011).

Min, J.U., Kim, Y. \& Ha, H. 2006. Aligning reverse logistics into sustainable and scalable business organisation - a benchmarking study in high-tech industry. Journal of International Logistics and Trade, 4(1): 93-107. Available from: http://www.jro.ac.kr/kor/sc_03_01. asp?num=7 (Accessed 5 February 2008).

Mollenkopf, D.A. \& Closs, D.J. 2005. The hidden value in reverse logistics. Supply Chain Management Review, 9(5):34-43. Available from: ABI/Inform Global: http://proquest.umi. com. (Accessed: 29 October 2009). [Accessed: 2009-10-29].

Mollenkopf, D.A. \& Weathersby, H. 2004. Creating value through reverse logistics. LQ, 9(3):1-48. [Online] Available from: http://www.logisticsquarterly.com/issues/9-3/LQ_9-3. pdf (Accessed 12 July 2011).

Moore, J. 2006. Reverse logistics - the least used differentiator. Reverse Logistics Magazine, 4th ed., 1(4):10-11. Available from: www.RLmagazine.com (Accessed: 5 September 2007).

Mukhopadhyay, S.K. \& Setaputra, R. 2006. The role of 4PL as the reverse logistics intergrator: optimal pricing and return policies. International Journal of Physical Distribution \& Logistics Management, 36(9):716-29. Available from: www.emeraldinsight.com/0960-0035.htm (Accessed 5 May 2007).

Norek, C.D. 2002. Returns management making order out of chaos. Supply Chain Management Review, 34-43. Available from: http://www.highbeam.com (Accessed 30 February 2007).

Norman, L. 2007. Reverse logistics - the bearer of good fortune. Available from: http:// www.takesupplychain.com/news-article-11-30-07.php (Accessed 7 August 2011).

Pollock, W.K. 2007. Using reverse logistics to enhance customer service and competitive performance. Reverse Logistics Magazine, 2(5):12-16. Available from: www.RLmagazine. com (Accessed 5 May 2011).

Pollock, W.K. 2010. Driving return process directly to the bottom line. Reverse Logistics Magazine, 3(5):12-16. Available from: www.RLmagazine.com (Accessed 5 May 2011). 
Ravi, V. \& Shankar, R. 2004. Analysis of interactions among the barriers of reverse logistics. Technological Forecasting \& Social Changes. Available from: eprint.iitd.ac.in/dspace/ bitstream/2074/1441/1/raviana2005.pdf (Accessed 21 August 2007).

Richardson H.L. 2006. Looking forward in reverse. Logistics Today, 47(7):20-22. Available from: http://www.proquest.com (Accessed 2 February 2008).

Richey, R.G., Daugherty, P.J., \& Genchev, S.E. 2005a. The role of resource commitment and innovation in reverse logistics performance. International Journal of Physical Distribution \& Logistics Management, 35(4):233-57. Available from: http://www.emeraldinsight.com (Accessed: 16 July 2007).

Richey, R.G., Tokman, M., Wright, R.R. \& Harvey, M.G. 2005b. Monitoring reverse logistics programs: a roadmap to sustainable development in emerging markets. Multinational Business Review, 13(3):41-65. Available from: http://www.proquest.com (Accessed 1 August 2007).

Riedel, M. 2004. Turning returns to profits. Traffic World. Newark: 1. Available from: http:// www.proquest.com (Accessed 22 August 2009).

Rogers, D., Lambert, D.M., Croxton, K.J. \& García-Dastugue, S.J. 2002. The returns management process. International Journal of Logistics Management, 13(2):1-18.

Rogers, D.S. \& Tibben-Lembke, R.S. 1998. Going backwards: reverse logistics trends and practices. Reverse Logistics Executive Council. Available from: www.rlec.com (Accessed 8 June 2007).

Rogers, D.S. \& Tibben-Lembke, R.S. 2001. An examination of reverse logistics practices. Journal of Business Logistics, 22(2):129-48. Available from: www.emeraldinsight.com (Accessed 15 June 2007).

Schwartz, B. 2000. Reverse logistics strengthens supply chains. Transportation \& Distribution, 41(5):95-98. Available from http://www.proquest.com (Accessed 1 August 2007).

Srivastava, S.K. 2007. Green supply-chain management: a state-of-the-art literature review. International Journal of Management Reviews, 9(1):53-80.

Sumner, W. 2008. Reverse logistics: it pays to do it right. Available from: http://www. inboundlogistics.com/articles/viewpoint/viewpoint0208.shtml (Accessed 12 August 2011).

supplychainforesight. 2011. Evolving strategies - Competitive supply chains in emerging economies. Available from: http://www.barloworld-logistics.com/bwlogistics/content/en/ global-supplychainforesight-reports (Accessed 2 September 2011). 
Thrikutam, P. \& Kumar, S. 2004. Turning returns management into a competitive advantage in hi-tech manufacturing. Available from: http://www.mid-hudsonapics.org/LinkedDocuments/ Infosys_Returns_Management_Hitech_Manufacturing.pdf (Accessed 18 July 2011).

Vogt, J.J., Pienaar, W.J. \& de Wit, P.W.C. 2002. Business logistics management: theory and practices. South Africa: Oxford University Press.

Weers, J. 2008. Integration of forward and reverse value chains. Reverse logistics magazine, 4(3):36. Available from: www.RLmagazine.com (Accessed 29 November 2010).

Yimsiri, S. 2009. Designing multi-objective reverse logistics networks using genetic algorithms. Arlington. The University of Texas. Ph.D. Available from: https://dspace.uta.edu/ bitstream/handle/10106/1678/Yimsiri_uta_2502D_10228.pdf?sequence=1 (Accessed 12 October 2011).

Zheng, Y., Zheng, W. \& Liu, P. 2005. Research on Information Integration Management of Reverse Logistics. ACM International Conference Proceeding Series of 7th International Conference on Electronic Commerce, 133:851-55 ACM: NY. Available from: http://www. proquest.com (Accessed 6 July 2009)

Zuluaga, J.P. 2005. Reverse logistics: models and applications. Department of Economics and Business Management - Graduate Program in Economics, Management and Finance. Universitat Pompeu Fabra. Available from: http://www.tdx.cesca.es/TDX-0203106-130305/ index_an.html (Accessed: 21 August 2007).

\section{Table of acronyms}

\begin{tabular}{|l|l|}
\hline CRM & Customer Relationship Management \\
\hline CSC & Closed-Loop Supply Chains \\
\hline CSCM & Closed-Loop Supply Chain Management \\
\hline CSCMP & Council of Supply Chain Management Professionals \\
\hline ERIM & Erasmus Research Institute of Management \\
\hline ERP & Enterprise Resource Planning \\
\hline GSCM & Green Supply Chain Management \\
\hline RLEC & Reverse Logistics Executive Council \\
\hline RSCM & Reverse Supply Chain Management \\
\hline SCM & Supply Chain Management \\
\hline WMS & Warehouse Management Systems \\
\hline
\end{tabular}

